\title{
The Anti-allergic Cromones: Past, Present, and Future
}

\author{
Ajantha Sinniah ${ }^{1 *}$, Samia Yazid² and Roderick J. Flower ${ }^{3}$ \\ ${ }^{1}$ Department of Pharmacology, Faculty of Medicine, University of Malaya, Kuala Lumpur, Malaysia, ${ }^{2}$ Trio Medicines Ltd., \\ Hammersmith Medicines Research, London, United Kingdom, ${ }^{3}$ Centre for Biochemical Pharmacology, William Harvey \\ Research Institute, St Barts and the Royal London School of Medicine, Queen Mary University of London, London, \\ United Kingdom
}

The anti-allergic cromones were originally synthesized in the 1960s by Fisons Plc, and the first drug to emerge from this program, disodium cromoglycate was subsequently marketed for the treatment of asthma and other allergic conditions. Whilst early studies demonstrated that the ability of the cromones to prevent allergic reactions was due to their 'mast cell stabilizing' properties, the exact pharmacological mechanism by which this occurred, remained a mystery. Here, we briefly review the history of these drugs, recount some aspects of their pharmacology, and discuss two new explanations for their unique actions. We further suggest how these findings could be used to predict further uses for the cromones.

Keywords: cromones, PKC, Annexin A1/FPR, GPR35, PP2A

\section{OPEN ACCESS}

Edited by:

Stefania Tacconelli,

Università degli Studi "G. d'Annunzio"

Chieti - Pescara, Italy

Reviewed by:

Sergey V. Ryzhov,

Maine Medical Center, United States Lina Lim,

National University of Singapore,

Singapore

*Correspondence:

Ajantha Sinniah

ajantha.sinniah@um.edu.my

Specialty section:

This article was submitted to

Inflammation Pharmacology,

a section of the journal

Frontiers in Pharmacology

Received: 12 July 2017 Accepted: 31 October 2017 Published: 14 November 2017

Citation:

Sinniah A, Yazid S and Flower RJ (2017) The Anti-allergic Cromones:

Past, Present, and Future.

Front. Pharmacol. 8:827.

doi: 10.3389/fphar.2017.00827

\section{HISTORY OF CROMONES}

The prototypical cromone, disodium cromoglycate, (cromolyn sodium) was introduced into clinical medicine in the early 1960s by the pharmaceutical company Fisons Plc. It arose from a study of the anti-spasmodic properties of the Egyptian medicinal herb Khellin. The experimental trail leading to the discovery of the anti-allergic properties of this compound and its clinical validation by the Fisons' pharmacologist, Roger Altounyan (himself an asthmatic), which entailed considerable self-experimentation, have become the stuff of pharmacological legend and will not be recounted here (see Howell, 2005). Originally, disodium cromoglycate was introduced for the treatment of mild-moderate allergic asthma. Although largely superseded by other medicines, it remains in the allergist's cache today and has maintained a stature as an effective drug with a good safety margin. In 1970s, Fison's developed nedocromil (Cairns et al., 1985), which not only shares a close chemical resemblance to cromoglycate, but also portrays comparable or even higher efficacy in the clinical setting. Subsequently, these drugs (often generically referred to as 'cromones') were also used to treat other allergic conditions (e.g., intestinal allergies, mastocytosis, and other allergic skin conditions).

Detailed research into the pharmacological actions of cromoglycate and nedocromil indicated that they inhibited mast cell degranulation provoked by various stimuli and thus these drugs were dubbed 'mast cell stabilizers' (Cox, 1967). In this respect, it was clear that the cromones had a distinctive mechanism of pharmacological action. Their 'mast cell stabilizing' effect (Vane, 1971; Thomson and Evans, 1973; Theoharides et al., 2000; Bandeira-Melo et al., 2005; Yazid et al., 2009) was clearly dissimilar to other drugs such as the $\beta$-agonists which, although more efficient at inhibiting mast cell degranulation (Shichijo et al., 1998), did not share other pharmacological characteristics of the cromones.

There are several disadvantages to using disodium cromoglycate therapeutically. It had to be administered at frequent intervals because of its poor pharmacokinetics and short half-life. Prophylactic treatment was essential and, for asthmatics, inhalation was the most reliable route 
of administration as this maximized the concentration in the lung. Despite this, and whilst inferior to the glucocorticoids for the treatment of asthma and allergies, these drugs have retained a niche role with a reputation for being very well tolerated and especially useful in pediatric formulations.

\section{CROMONE PHARMACOLOGY}

In addition to their effect on mast cells, several other actions of cromoglycate-like drugs have been reported which might be classified as 'anti-inflammatory'. These include inhibition of activation (Kay et al., 1987), migration (Bruijnzeel et al., 1993; Szkudlińska et al., 1996) of polymorphonuclear (PMN) leukocytes; macrophage activation (Joseph and Rainey, 1992), mediator (Dahlén et al., 1989), and tachykinin action (Yamawaki et al., 1997); eicosanoid (Mattoli et al., 1990; Radeau et al., 1993) and cytokine release (Rusznak et al., 1996) as well as adhesion molecule expression (Hoshino and Nakamura, 1997; Okada et al., 1999; Sacco et al., 1999; Vural et al., 2000) and blockade of chloride channels (Alton and Norris, 1996; Heinke et al., 1995; Norris and Alton, 1996). It is not clear whether their mast cell stabilizing effect alone is responsible for their anti-asthmatic action in humans, (but it probably underlies their anti-allergic action), however, there is a widely-accepted notion that cromoglycate and nedocromil render their antiasthmatic effects due to a combination of these anti-inflammatory actions (Cairns et al., 1985). Given that inflammatory diseases are associated with pro-inflammatory stimuli in pathological setting, 'mast cell stabilizing' properties of cromones were tested not only in the presence of Ig-E (Leung et al., 1988; Oka et al., 2012; Yazid et al., 2013), but also using the mast cell secretagogue such as compound 48/80 (Jeong et al., 2006; Sinniah et al., 2016). Nonetheless, typical inducers of inflammation such as lipopolysaccharide (LPS) (Nava and Caputi, 1999; Oka et al., 2012; Zhang X. et al., 2016; Hughes et al., 2017), phorbol 12myristate 13-acetate (PMA) (Sadeghi-Hashjin et al., 2002; Yazid et al., 2009) and TNF- $\alpha$ (Bissonnette et al., 1995) were also utilized to elucidate the mechanism of action of cromone. To identify the pharmacological actions of cromones in vivo settings, various inflammatory models were used to assess the mast cell function (Wyss et al., 2005; Kneilling et al., 2007; Hei et al., 2008; Liu et al., 2009; Ramos et al., 2010; Zhang S. et al., 2016; Hughes et al., 2017).

Despite earlier studies led to the notion that the cromoglycatelike drugs acted largely on mast cells (Cox, 1967, 1970; Cox and Altounyan, 1970; Cox et al., 1970; Orr, 1989) to inhibit the release of mediators, current evidence suggest that this is unlikely to be their sole target of action and that these drugs do exert pharmacological effect in non-allergic settings. Indeed, work from our own group (Yazid et al., 2010b) have shown that cromones inhibit neutrophil recruitment onto vascular endothelium, further suggesting that these drugs could play a role in diseases such as gouty arthritis and vasculitis, which are steered by excessive PMN activation. Clearly, it could be argued that cromones impede PMN trafficking by inhibiting the release of mediators from mast cells, however, a study by Furuta et al. (1998), have shown that there is a separate and direct effect of cromones on PMN, which does not require mast cell participation. Interestingly, cromoglycate-like drugs also targets inhibition of eicosanoids release (Mattoli et al., 1990; Radeau et al., 1993; Yazid et al., 2009) and cytokine production (Kimata et al., 1994; Devalia et al., 1996; Yazid et al., 2013), which further reiterates the concept that cromones' actions are not only limited to allergic inflammation.

\section{POTENTIAL THERAPEUTIC MECHANISMS}

Early investigations of cromoglycate action on mast cell degranulation highlighted several unusual features. The cromones appeared to exhibit strong tachyphylaxis (Sung et al., 1977a,b; Church and Hiroi, 1987) and the timing of the drug administration relative to the degranulating agent was also crucial in determining their pharmacological effect (Shichijo et al., 1998). Tachyphylaxis is so prominent that the blocking effect of the drug often cannot be repeated within a defined time-frame (Thomson and Evans, 1973) and if the drug was administered too far in advance of the degranulating stimulus, it was ineffective. These observations have led to speculations that cromoglycate released a substance, which once exhausted, required replenishment before the next challenge could be effective (Thomson and Evans, 1973). Other incongruities observed with these drugs were connected with the optimal concentration required for the inhibition of mast cell degranulation in vitro, since there were discrepancies amongst species and between mast cell subtypes, in their response to cromones (Church and Hiroi, 1987; Kay et al., 1987; Pearce et al., 1982). One group has even questioned whether cromoglycate, which is highly active in the rat, has any efficacy in the mouse (Oka et al., 2012). An interesting observation has shown that cromoglycate induced the phosphorylation of a $78 \mathrm{kD}$ mast cell protein, which inhibits mast cell activation (Wells and Mann, 1983). However, in the presence of phorbol esters, these drugs loses this ability, and render inactive (Cox et al., 1998). This phenomenon further suggests that cromoglycate is involved in an endogenous control mechanism that switches off the release of mediators.

\section{A Role for PKC?}

There have been dispersed reports of an association between cromoglycate and PKC over the past 3 decades (Lucas and Shuster, 1987; Bansal et al., 1997). A consistent finding has been that these drugs increase the phosphorylation of some cellular proteins. For example, cromoglycate induced the phosphorylation of several intracellular protein substrates including the erythrocyte band 4.1 group protein moesin in rat mast cells (Theoharides et al., 1980; Theoharides et al., 2000). Theoharides et al. (2000) have identified four phosphoproteins with molecular weights of 78, 68, 59, and $42 \mathrm{kDa}$ in mast cells treated with cromoglycate. The authors suggested that the $78 \mathrm{kDa}$ phosphoprotein (later cloned and characterized as cellular cytoskeletal protein moeisin) might be the molecular switch that regulates the degranulation process 
in mast cells, since the appearance of this protein coincide with the secretory phase stimulated by compound $48 / 80$. The authors speculated that conformational changes of moesin at differential phosphorylation sites regulates the mast cell secretory mechanism, and PKC was identified to be the most likely kinase to be involved in this phosphorylation process (Wang et al., 1999).

PKC has also been associated in the action of cromoglycate in several different models by other investigators (Sagi-Eisenberg, 1985). Some reports have shown that PKC is inhibited by cromoglycate, however discrepancies between the time courses and methodologies obscure clear interpretation of these results.

\section{GPR 35 Activation}

A novel mechanism of cromone action was proposed by two groups (Jenkins et al., 2010; Yang et al., 2010), who suggested that they act through GPR35, a G-protein coupled receptor that modulates signaling via the Gi pathway. This GPCR was previously regarded as an orphan receptor, and its endogenous ligands have been identified as products of tryptophan metabolism, such as kynurenic acid, although fairly high concentrations of these ligands are required to activate the receptor (Wang et al., 2006).

Yang et al. (2010) demonstrated that cromoglycate, nedocromil and zaprinast (another non-cromone anti-allergic) increased inositol phosphate accumulation and calcium mobilization in HEK cells transfected with GPR35. Although there were differences in the specificity exhibited by these drugs when tested on human, mouse and rat GPR35, all three drugs exerted similar potency.

Another study identified a range of ligands including dicoumarol, cromoglycate, and zaprinast in HEK cells transfected with human and rat GPR35, using a $\beta$-arrestin- 2 interaction assay. Dicoumarol was a partial agonist whilst cromoglycate and zaprinast were full agonist (Jenkins et al., 2010).

GPR35 is present on human mast cells (particularly following treatment with IgE), as well as on eosinophils and basophils. However, its significance to asthma and allergy or to mast cell mediator release is yet to be elucidated, thus it is unclear how these actions of the cromones could be translated into therapeutic effects. Nevertheless, one of the downstream effects of GPR35 activation is activation of PKC so this mechanism would certainly contribute to the observed changes of phosphoprotein abundance in cells.

\section{The Anx-A1/FPR System}

In recent years, our laboratory has proposed a new mechanism to account for cromone action. According to this hypothesis, these drugs activate an endogenous anti-inflammatory loop, the Anx$A 1 / F P R$ system, which regulates cell activation in many cell types (Yazid et al., 2010b; Sinniah et al., 2016). Interestingly, there are other reports (Oyama et al., 1997; Shishibori et al., 1999) of an association between the annexin family and cromoglycate drugs, whereby these drugs were observed to have an affinity for S100 proteins. It is worth noting that $\mathrm{S} 100$ proteins are intracellular binding partners for some members of the annexin family and play a significant role in membrane fusion events (Rintala and Lindahl, 2001).

Anx-A1 is a $37 \mathrm{kDa}$ monomeric protein that is commonly found in many differentiated cells, mainly those of the myeloid lineage (Perretti and D'Acquisto, 2009). It is a member of a superfamily of proteins, which are of ancient evolutionary origin and which are common in most eukaryotic cells (Gerke and Moss, 2002). Structurally, annexins contain a number of homologous core domain repeats attached to an N-terminus of differing lengths that contributes to the various diversity between annexin isoforms (Moss and Morgan, 2004). In mammals, there are 12 annexins and Anx-A1 (numbering corresponds to the first one to be cloned) has four conserved repeats in the core domain. These units has binding motifs for calcium, phosphatidylserine and negatively charged phospholipids (Raynal and Pollard, 1994).

Prior to its cloning, sequencing and characterization (Wallner et al., 1986), Anx-A1 (also known in the older literature as 'macrocortin', 'renocortin', 'lipomodulin', and 'lipocortin') was recognized by its characteristic biological activity (Blackwell et al., 1980; Hirata, 1981; Russo-Marie and Duval, 1982; Pepinsky et al., 1986). It was first detected in the conditioned media or perfusate of tissues or cells upon treatment with glucocorticoids, and was found to mirror the action of these drugs in numerous in vitro and in vivo systems (Pepinsky et al., 1986). The synthesis and release of this protein were hypothesized to account for some of the anti-inflammatory actions of these drugs and this was confirmed by later experiments using the highly purified r-huAnx-A1 (Cirino and Cicala, 1993; Perretti et al., 1993; Wu et al., 1995; D’Amico et al., 2000; Gavins et al., 2003; Bandeira-Melo et al., 2005), Anx-A1-deficient transgenic animals (Roviezzo et al., 2002; Croxtall et al., 2003; Hannon et al., 2003), neutralizing antibodies (Croxtall and Flower, 1992; Duncan et al., 1993; Perretti et al., 1996; Teixeira et al., 1998), and anti-sense agents (Croxtall and Flower, 1994; Taylor et al., 1997). Anx-A1 is now known to exert a key 'anti-inflammatory and pro-resolution' role in several important host defense responses including acute inflammation (Perretti and D'Acquisto, 2009) and T-cell signaling (D’Acquisto et al., 2008).

The mechanism by which glucocorticoids (and other factors) promote the actions of Anx-A1 has also been investigated in detail (Croxtall et al., 1996, 2000; Parente and Solito, 2004). In many systems including cells of the innate immune system (e.g., macrophages), glucocorticoids have not only been found to promote Anx-A1 synthesis through genomic action, but also to trigger the rapid release of pre-existing pools of AnxA1 from the cell cytoplasm (Croxtall et al., 2000). The latter mechanism is modulated by $\mathrm{PKC}$, whereby phosphorylation of Anx-A1 at $\operatorname{Ser}^{27}$ and other residues initiates the translocation of Anx-A1 to the plasma membrane and subsequently its release from the cell (Solito et al., 2006). Anx-A1 can then interact with its target cells in an autocrine or paracrine manner by activating receptors of the FPR family, probably ALX/FPR2 in man or, in the mouse, its homolog Fpr2 (Walther et al., 2000; Dufton et al., 2010). Recent literature has shown that FPR2 and FceR1 co-localize when mast cells are stimulated with $\mathrm{N}$ formyl-methionyl- leucyl-phenylalanine (fmlp) and IgE antigen, leading to mast cell activation (Xue et al., 2007). This adds to 
the conundrum on how FPR could be involved in both the activation and inhibition of mast cell degranulation? One unique feature of FPR2 is that it recognizes both pro-inflammatory and anti-inflammatory signals. Liganding of this receptor by AnxA1 causes it to dimerize, activating a downstream signaling pathway and producing the generally inhibitory effect that AnxA1 has on cell activation (Cooray et al., 2013). Interestingly, this receptor can also transduce pro-inflammatory signals: in this case, dimerization does not occur and a different signaling pathway is brought into play.

Proteolysis is vital in determining the extent of secreted AnxA1 action and disturbances of this process may be a trigger in some diseases. In Wegener's granulomatosis (for example), extreme PMN activation could be trailed down to abnormal Anx-A1 cleavage by the PR3 protease (Pederzoli-Ribeil et al., 2010).

Mast cells, one of the principal targets of cromoglycate action contain abundant Anx-A1 and respond rapidly to glucocorticoid treatment with an increase in Anx-A1 mRNA (Oliani et al., 2000). These cells also express the Anx-A1 receptor, ALX/FPR2. The sub-cutaneous injection of the mast cell secretagogue compound 48/80 into the flank of mice produces a greater wheal in AnxA1 null mice compared to its wild type counterpart (Yazid et al., 2010a). In addition, mast cells in Anx-A1 'knock-out' mice are more susceptible to degranulation, hence release more $\mathrm{PGD}_{2}$ and histamine than wild type cells in response to degranulating stimulants (Damazo et al., 2005). The acute inhibitory action of cromones as well as glucocorticoids on mast cell mediator release is blocked in the presence of specific anti-Anx-A1 neutralizing antibodies (Sinniah et al., 2016). All these observations suggest that Anx-A1 exerts a 'homeostatic' inhibitory influence on mast cell reactivity and is important in the mode of action of the cromones.

To further support this notion, a complementary study in which administration of the biomimetic Anx-A1 N-terminal peptide Ac 2-26 inhibited IgE-induced histamine release in the pleural cavity (Bandeira-Melo et al., 2005) strongly suggests that Anx-A1 is also an endogenous regulator of mast cell degranulation in an experimental model of rat allergic pleuritis.

\section{Action of Cromones on the PP2A Phosphatase}

In view of the fact that the cromoglycate-like drugs act as mast cell stabilizers, and that Anx-A1 is clearly implicated in mast cell biology, an obvious hypothesis was that the cromoglycatelike drugs could release Anx-A1, which then mediated the pharmacological actions of these drugs. A simple model for studying the biological actions of Anx-A1 release under closely defined conditions was utilized to investigate this possibility (Yazid et al., 2009).

U937 cells were used as these cells are responsive to glucocorticoids when differentiated, contains abundant Anx-A1 and produces a convenient biochemical readout of activation. This study concluded that thromboxane $(\mathrm{Tx}) \mathrm{B}_{2}$ production was suppressed when glucocorticoids such as dexamethasone initiate the phosphorylation and release of Anx-A1, that the phosphorylation of Anx-A1 precedes export and that PKC was the kinase most likely responsible for this action. Occupancy of the glucocorticoid receptor prompts PKC activation. Although the mechanism is not well elucidated, some observations have implicated the involvement of PIP3 kinase in this activation (Solito et al., 2003).

Yazid et al. (2009) had speculated that some interaction occurred between the acute effect of dexamethasone and the action of cromoglycate, although the reason for this interaction was unclear at that time. Analysis of Anx-A1 in U937 cells revealed that whilst dexamethasone produced a small increase in phosphorylated and externalized Anx-A1, the addition of cromoglycate alone was without effect. A study of the dynamics of the glucocorticoid-induced phosphorylation of Anx-A1 at the $\mathrm{Ser}^{27}$ residue showed that the effect seen was very rapid with a maximum activation of PKC and Anx-A1 phosphorylation occurring within $5 \mathrm{~min}$. Whilst the cromones alone had little effect on Anx-A1 phosphorylation, they greatly potentiated the effect of the glucocorticoids (see Figure 1). This was evident by the redistribution of GFP-tagged Anx-A1 within the U937 cells, extracellular accumulation of the protein and, dramatically, by the observed inhibition of $\mathrm{TxB}_{2}$ generation. For example, the inhibition of $\mathrm{TxB}_{2}$ release in $\mathrm{U} 937$ cells treated with $2 \mathrm{nM}$ of dexamethasone alone was only $<20 \%$, but this inhibition was increased to almost $100 \%$ in the presence of $20 \mathrm{nM}$ nedocromil at $5 \mathrm{~min}$ time point. Cromolycate also has similar glucocorticoid potentiating ability.

The regulation of PKC activity may be accomplished through several potential mechanisms. The duration of action of PKC is limited by phosphatases such as PP2A. PKC $\alpha$ (and some other isoforms) interact with PP2A following activation in many cell types, including macrophage (see review Sim and Scott, 1999). PKC activation is followed by its translocation to the plasma membrane (see Refs. Ishizuka et al., 1995; Park

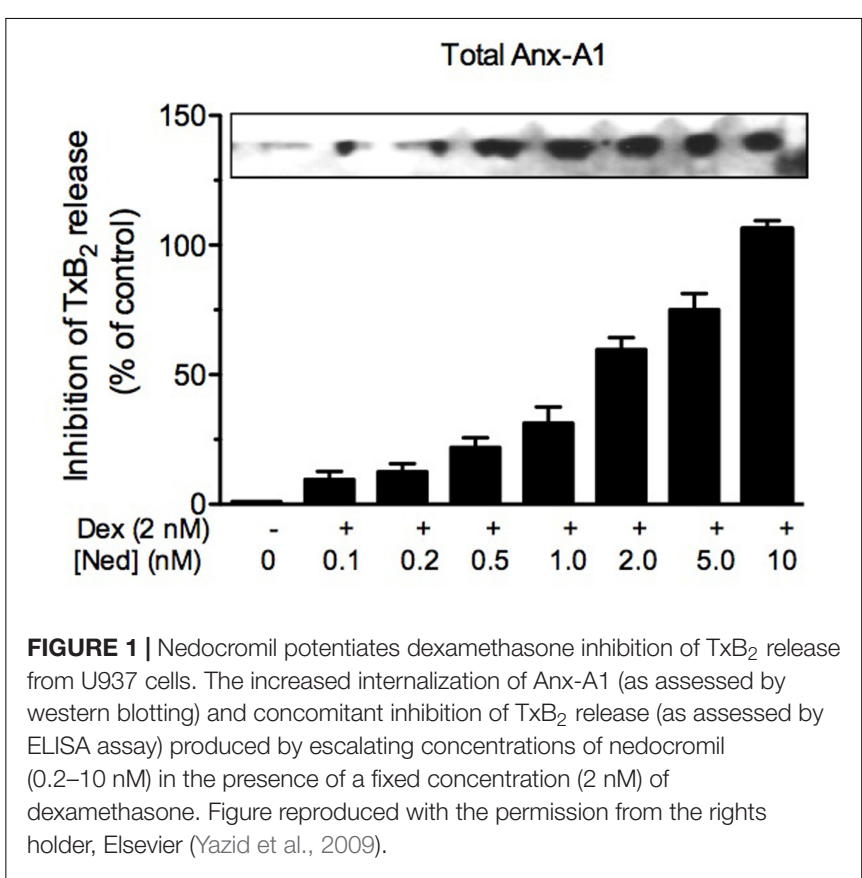


et al., 2001; Qiu et al., 2003; Plotkin et al., 2007) where its catalytic activity is terminated by the phosphatase, which limits the duration of its biological actions (Sagi-Eisenberg, 1985; Ricciarelli and Azzi, 1998; Boudreau et al., 2002; Faulkner et al., 2003; Zhang et al., 2007; Lee et al., 2008). Another possibility is modulation of diacylglycerol (DAG) activity. DAG is the endogenous activator of PKC, but is rapidly destroyed by DAG kinases which therefore also terminate PKC activation. It follows that inhibitors of either of these two processes should greatly potentiate the glucocorticoid-induced increase in Anx-A1 phosphorylation and release from cells. One possibility therefore was that the cromones were in fact inhibitors of PP2A.

Previous experimental observations had revealed that GC receptor ligation, perhaps acting through phosphatidylinositol 3-kinase (Solito et al., 2003), causes PKC activation and membrane translocation and that this activity was limited by dephosphorylation, through the Ser/Thr PP2A phosphatase (Hansra et al., 1996). Further support for a mechanism of this type in the U937 cell system was obtained in an experiment with the PP2A inhibitor okadaic acid (OA). Treatment of these cells with OA greatly potentiated the effect of dexamethasone on Anx-A1 externalization and eicosanoid synthesis (Yazid et al., 2009).

This hypothesis was further tested by assessing the ability of nedocromil and cromoglycate to inhibit the endogenous phosphatase activity found in the membrane fraction of U937 cells following treatment with dexamethasone. These drugs strongly inhibited this phosphatase activity and similar findings were reported when highly purified recombinant PP2A was used as a target enzyme (Yazid et al., 2009).

PP2A is a heterotrimeric enzyme comprising one each of two variant catalytic and structural sub-units together with one (of a family of about twenty) modulatory/targeting sub-unit, which determines the specificity of the assembled enzyme complex. C-terminal carboxymethylation of the catalytic sub-unit at $\mathrm{Leu}^{309}$ activates PP2A probably by facilitating the formation of trimeric complexes (Lee et al., 2007; Yoo et al., 2007; Ortega-Gutiérrez et al., 2008). The enzyme may be phosphorylated on $\mathrm{Tyr}^{307}$ by either receptor or other tyrosine kinase action (Chen et al., 1992) which may be the way in which the phosphatase activity itself is terminated at the membrane. However, the importance of these post-translational modifications to enzyme activity in vitro and in vivo is not yet entirely clear (Sim and Scott, 1999).

It is likely from the available experimental evidence that the cromones interact with the catalytic site of the trimeric PP2A complex. This contains $\mathrm{Mn}^{2+}$ which might possibly be a target for the drugs which could conceivably interact with this metal being carboxylic acids (unpublished data). Interestingly, previous authors had already investigated the possibility that cromones inhibited PP2A, but were unable to detect an effect in their

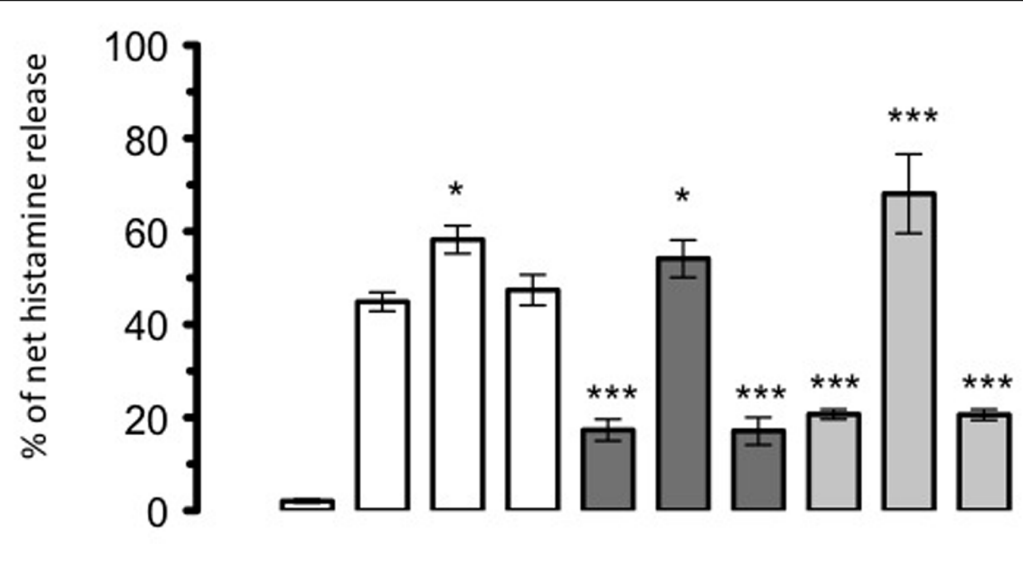

Cpd 48/80 (10 $\mu \mathrm{g} / \mathrm{ml})$

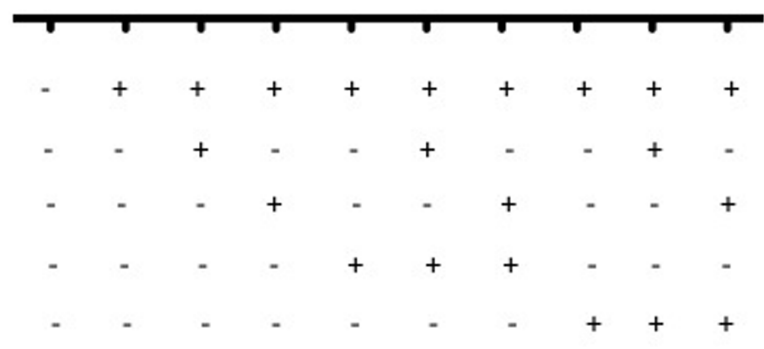

FIGURE 2 | The inhibition by nedocromil and ketotifen of mediator release from Cord blood derived mast cells (CBDMCs) stimulated with compound 48/80 is dependent upon Anx-A1. CBDMCs were plated at a density of $2 \times 10^{5}$ cells per well and the stipulated groups were treated with $20 \mu \mathrm{g} / \mathrm{ml}$ Anx-A1 neutralizing antibody or an irrelevant isotype control. Subsequently, the cells were pre-treated with either nedocromil (10 nM) or ketotifen (10 nM) for 5 min followed by compound 48/80 (10 $\mu \mathrm{g} / \mathrm{ml})$ stimulation for $10 \mathrm{~min}$. To assess the effects of Anx-A1 removal, the cells were incubated with the Anx-A1 neutralizing antibody (or an irrelevant isotype control) only. Nedocromil and ketotifen produced consistent inhibition of histamine, but not control isotype matched non-neutralizing mAb. Data are expressed as mean \pm SEM from $n=3$ experiment and were analysed using one-way analysis of variance (ANOVA), followed by a Bonferroni post hoc test, ${ }^{*} p<0.05,{ }^{* * *} p<0.001$ vs unstimulated). Figure reproduced with the permission from the rights holder, Elsevier (Sinniah et al., 2016). 
system (Wang et al., 1999). However, some groups had noted a link between the action of these drugs in vivo and inhibition of alkaline phosphatase in a rat passive cutaneous anaphylaxis model (Schwender, 1981; Schwender et al., 1982).

Increased Anx-A1 release reflected the inhibitory actions of combined nedocromil and dexamethasone treatment (Sinniah et al., 2016). An additional interesting observation from this study was that depletion of Anx-A1 in vitro completely reversed the inhibitory actions of these drugs (see Figure 2). This mechanism was also observed to operate in vivo. Using Anx-A1 null mice, the ability of nedocromil to inhibit leukocyte migration in a model of peritoneal inflammation in mice was lost whilst they were fully active in the wild type (Yazid et al., 2010b).

\section{Other Drugs Which May Operate Using the Anx-A1/FPR Pathway}

Several other drugs, including some non-cromone antiallergic/anti-histamines (including azelastine, pemirolast, and olopatidine) exhibit cross-tachyphylaxis, or share a similar pharmacology, with cromones (Cook et al., 2002).

One such drug is the second-generation $\mathrm{H}_{1}$ antagonist ketotifen. When tested, ketotifen was found to have the same effect on the Anx-A1 system as nedocromil and cromoglycate suggesting a commonality of mechanisms of action (Sinniah et al., 2016). An important speculation is that all $\mathrm{H}_{1}$ antagonists with this additional action may have a secondary pharmacology as PP2A inhibitors and, if so, this could be a beneficial therapeutic screen to evaluate this property.

\section{The Future of Cromone Pharmacology}

The demonstration by our group that the cromones potentiate the acute effect of glucocorticoids on Anx-A1 release could have some clinical implications as Anx-A1 has been implicated in the regulation of bronchial hyper-reactivity and asthma, at least in animals ( $\mathrm{Ng}$ et al., 2011). It begs the question of whether using a mixture of the two drugs would augment the response to glucocorticoids perhaps permitting a reduction in the dose required to achieve a therapeutic effect. An understanding of the mechanism of action of these drugs will enable - for the first time - the creation of a simple biochemical screen or readout for testing future cromone or other derivatives with presumed anti-allergic properties.

Of course, Anx-A1 is not the sole substrate for PKC, so other PKC-dependent phosphorylation events might be potentiated in the presence of the cromones. We have already mentioned an early observation that increases in the phosphorylation of moesin

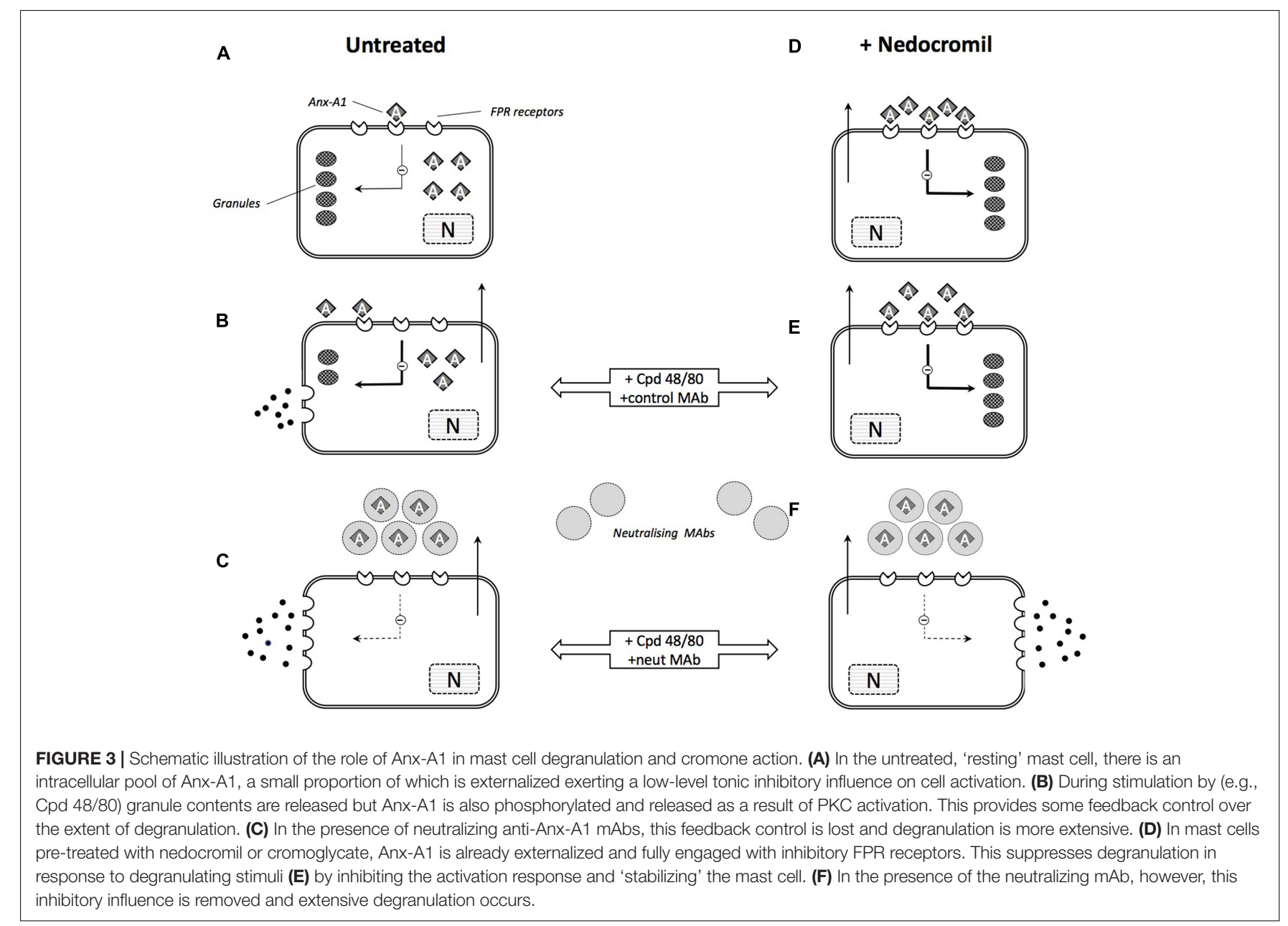


and several other proteins have been observed in the presence of these drugs. What other targets might there be in the cell? One significant target may be the glucocorticoid receptor. Whilst the acute increase in Anx-A1 secretion we have observed is due entirely to an increased secretion of the protein, we are aware that the glucocorticoid receptor itself is phosphorylated upon liganding, possibly by PKC, and that PP2A (which is associated with the receptor complex) plays a key role in terminating its activation after an appropriate time period (Kobayashi et al., 2017). One might predict changes in glucocorticoid receptor behavior in the presence of cromones although how this would play out in terms of their therapeutic action will have to be investigated.

The possible mechanism of action by cromone in mast cells is summarized in Figure 3.

\section{CONCLUSION}

To conclude, we have reviewed evidence supporting the hypothesis that Anx-A1 is indeed a crucial endogenous regulator of mast cell function, which might reciprocally inhibit mast cell activation. Anx-A1 is secreted in increased amounts parallel

\section{REFERENCES}

Alton, E. W., and Norris, A. A. (1996). Chloride transport and the actions of nedocromil sodium and cromolyn sodium in asthma. J. Allergy Clin. Immunol. 98, S102-S105; discussion S105-S106. doi: 10.1016/S0091-6749(96)70024-6

Bandeira-Melo, C., Bonavita, A. G., Diaz, B. L., E Silva, P. M., Carvalho, V. F., Jose, P. J., et al. (2005). A novel effect for annexin 1-derived peptide ac2-26: reduction of allergic inflammation in the rat. J. Pharmacol. Exp. Ther. 313, 1416-1422. doi: 10.1124/jpet.104.080473

Bansal, S. K., Jha, A., Jaiswal, A. S., and Chhabra, S. K. (1997). Increased levels of protein kinase $\mathrm{C}$ in lymphocytes in asthma: possible mechanism of regulation. Eur. Respir. J. 10, 308-313. doi: 10.1183/09031936.97.10020308

Bissonnette, E. Y., Enciso, J. A., and Befus, A. D. (1995). Inhibition of tumour necrosis factor-alpha (TNF-alpha) release from mast cells by the antiinflammatory drugs, sodium cromoglycate and nedocromil sodium. Clin. Exp. Immunol. 102, 78-84. doi: 10.1111/j.1365-2249.1995.tb06639.x

Blackwell, G. J., Carnuccio, R., Di Rosa, M., Flower, R. J., Parente, L., and Persico, P. (1980). Macrocortin: a polypeptide causing the anti-phospholipase effect of glucocorticoids. Nature 287, 147-149. doi: 10.1038/287147a0

Boudreau, R. T., Garduno, R., and Lin, T. J. (2002). Protein phosphatase 2A and protein kinase Calpha are physically associated and are involved in Pseudomonas aeruginosa-induced interleukin 6 production by mast cells. J. Biol. Chem. 277, 5322-5329. doi: 10.1074/jbc.M108623200

Bruijnzeel, P. L., Warringa, R. A., Kok, P. T., Hamelink, M. L., Kreukniet, H., and Koenderman, L. (1993). Effects of nedocromil sodium on in vitro induced migration, activation, and mediator release from human granulocytes. J. Allergy Clin. Immunol. 92, 159-164. doi: 10.1016/0091-6749(93)90099-2

Cairns, H., Cox, D., Gould, K. J., Ingall, A. H., and Suschitzky, J. L. (1985). New antiallergic pyrano [3,2-g]quinoline-2,8-dicarboxylic acids with potential for the topical treatment of asthma. J. Med. Chem. 28, 1832-1842. doi: 10.1021/ jm00150a014

Chen, M. X., Chen, Y. H., and Cohen, P. T. (1992). Polymerase chain reactions using Saccharomyces, Drosophila and human DNA predict a large family of protein serine/threonine phosphatases. FEBS Lett. 306, 54-58. doi: 10.1016/ 0014-5793(92)80836-6

Church, M. K., and Hiroi, J. (1987). Inhibition of IgE-dependent histamine release from human dispersed lung mast cells by anti-allergic drugs and salbutamol. $\mathrm{Br}$. J. Pharmacol. 90, 421-429. doi: 10.1111/j.1476-5381.1987.tb08972.x with mediators during mast cell activation and thus, acts to control the extent of mast cell degranulation and activation response.

We also described a different, GPR35-dependent mechanism, which could also transduce some of the effects of the cromones. In trying to reconcile these two ideas, it is worth noting that the effects on the Anx-A1 system that was reported here was very rapid (within $5 \mathrm{~min}$ ) and that we have not looked at other actions of the cromones that may require a longer latent period, which could be mediated by an alternative GPR35 mechanisms.

\section{AUTHOR CONTRIBUTIONS}

All the authors contributed to the writing of the manuscript. AS prepared the final version and prepared the paper for publication.

\section{FUNDING}

This work was partly funded by The Wellcome Trust (award number 085903). AS was supported by the Government of Malaysia.

Cirino, G., and Cicala, C. (1993). Human recombinant lipocortin 1 (annexin 1) has anticoagulant activity on human plasma in vitro. J. Lipid Mediat. 8, 81-86.

Cook, E. B., Stahl, J. L., Barney, N. P., and Graziano, F. M. (2002). Mechanisms of antihistamines and mast cell stabilizers in ocular allergic inflammation. Curr. Drug Targets Inflamm. Allergy 1, 167-180. doi: 10.2174/1568010023344733

Cooray, S. N., Gobbetti, T., Montero-Melendez, T., McArthur, S., Thompson, D., Clark, A. J., et al. (2013). Ligand-specific conformational change of the G-protein-coupled receptor ALX/FPR2 determines proresolving functional responses. Proc. Natl. Acad. Sci. U.S.A. 110, 18232-18237. doi: 10.1073/pnas. 1308253110

Cox, A., Law, N. M., and Findlay, J. B. (1998). Inhibition of cromolyn-induced phosphorylation of a $78-\mathrm{kDa}$ protein by phorbol esters in rat peritoneal mast cells. Biochem. Pharmacol. 55, 585-594. doi: 10.1016/S0006-2952(97)00467-X

Cox, J. S. (1967). Disodium cromoglycate (FPL 670) ('Intal'): a specific inhibitor of reaginic antibody-antigen mechanisms. Nature 216, 1328-1329. doi: 10.1038/ $2161328 \mathrm{a} 0$

Cox, J. S. (1970). Recent developments concerned with the mode of action of disodium cromoglycate (Intal). Arerugi 19, 832-835.

Cox, J. S., and Altounyan, R. E. (1970). Nature and modes of action of disodium cromoglycate (Lomudal). Respiration 27(Suppl.), 292-309. doi: 10.1159/000192762

Cox, J. S., Beach, J. E., Blair, A. M., Clarke, A. J., King, J., Lee, T. B., et al. (1970). Disodium cromoglycate (Intal). Adv. Drug Res. 5, 115-196.

Croxtall, J. D., Choudhury, Q., and Flower, R. J. (2000). Glucocorticoids act within minutes to inhibit recruitment of signalling factors to activated EGF receptors through a receptor-dependent, transcription-independent mechanism. Br. J. Pharmacol. 130, 289-298. doi: 10.1038/sj.bjp.0703272

Croxtall, J. D., Choudhury, Q., Newman, S., and Flower, R. J. (1996). Lipocortin 1 and the control of cPLA2 activity in A549 cells. Glucocorticoids block EGF stimulation of cPLA2 phosphorylation. Biochem. Pharmacol. 52, 351-356. doi: 10.1016/0006-2952(95)02442-5

Croxtall, J. D., and Flower, R. J. (1992). Lipocortin 1 mediates dexamethasoneinduced growth arrest of the A549 lung adenocarcinoma cell line. Proc. Natl. Acad. Sci. U.S.A. 89, 3571-3575. doi: 10.1073/pnas.89.8.3571

Croxtall, J. D., and Flower, R. J. (1994). Antisense oligonucleotides to human lipocortin-1 inhibit glucocorticoid-induced inhibition of A549 cell growth and eicosanoid release. Biochem. Pharmacol. 48, 1729-1734. doi: 10.1016/00062952(94)90458-8 
Croxtall, J. D., Gilroy, D. W., Solito, E., Choudhury, Q., Ward, B. J., Buckingham, J. C., et al. (2003). Attenuation of glucocorticoid functions in an Anx-A1-/- cell line. Biochem. J. 371, 927-935. doi: 10.1042/bj20021856

D'Acquisto, F., Perretti, M., and Flower, R. J. (2008). Annexin-A1: a pivotal regulator of the innate and adaptive immune systems. Br. J. Pharmacol. 155, 152-169. doi: 10.1038/bjp.2008.252

Dahlén, S. E., Björck, T., Kumlin, M., Sydbom, A., Raud, J., Palmertz, U., et al. (1989). Dual inhibitory action of nedocromil sodium on antigen-induced inflammation. Drugs 37(Suppl. 1), 63-68. discussion 69-77, doi: 10.2165/ 00003495-198900371-00013

Damazo, A. S., Yona, S., D’Acquisto, F., Flower, R. J., Oliani, S. M., and Perretti, M. (2005). Critical protective role for annexin 1 gene expression in the endotoxemic murine microcirculation. Am. J. Pathol. 166, 1607-1617. doi: 10.1016/S0002-9440(10)62471-6

D’Amico, M., Di Filippo, C., La, M., Solito, E., McLean, P. G., Flower, R. J., et al. (2000). Lipocortin 1 reduces myocardial ischemia-reperfusion injury by affecting local leukocyte recruitment. FASEB J. 14, 1867-1869. doi: 10.1096/fj. 99-0602fje

Devalia, J. L., Rusznak, C., Abdelaziz, M. M., and Davies, R. J. (1996). Nedocromil sodium and airway inflammation in vivo and in vitro. J. Allergy Clin. Immunol. 98, S51-S57; discussion S64-S66. doi: 10.1016/S0091-6749(96)70017-9

Dufton, N., Hannon, R., Brancaleone, V., Dalli, J., Patel, H. B., Gray, M., et al. (2010). Anti-inflammatory role of the murine formyl-peptide receptor 2: ligand-specific effects on leukocyte responses and experimental inflammation. J. Immunol. 184, 2611-2619. doi: 10.4049/jimmunol.0903526

Duncan, G. S., Peers, S. H., Carey, F., Forder, R., and Flower, R. J. (1993). The local anti-inflammatory action of dexamethasone in the rat carrageenin oedema model is reversed by an antiserum to lipocortin 1. Br. J. Pharmacol. 108, 62-65. doi: 10.1111/j.1476-5381.1993.tb13440.x

Faulkner, N. E., Lane, B. R., Bock, P. J., and Markovitz, D. M. (2003). Protein phosphatase $2 \mathrm{~A}$ enhances activation of human immunodeficiency virus type 1 by phorbol myristate acetate. J. Virol. 77, 2276-2281. doi: 10.1128/JVI.77.3. 2276-2281.2003

Furuta, G. T., Wang, Z. S., and Wershil, B. K. (1998). Gastric inflammation during systemic anaphylaxis: neutrophil recruitment in stomach wall of mice does not require mast cell participation. Dig. Dis. Sci. 43, 2021-2027. doi: 10.1023/A: 1018851012940

Gavins, F. N., Yona, S., Kamal, A. M., Flower, R. J., and Perretti, M. (2003). Leukocyte antiadhesive actions of annexin 1: ALXR- and FPR-related antiinflammatory mechanisms. Blood 101, 4140-4147. doi: 10.1182/blood-2002$11-3411$

Gerke, V., and Moss, S. E. (2002). Annexins: from structure to function. Physiol. Rev. 82, 331-371. doi: 10.1152/physrev.00030.2001

Hannon, R., Croxtall, J. D., Getting, S. J., Roviezzo, F., Yona, S., Paul-Clark, M. J., et al. (2003). Aberrant inflammation and resistance to glucocorticoids in annexin 1-/- mouse. FASEB J. 17, 253-255.

Hansra, G., Bornancin, F., Whelan, R., Hemmings, B. A., and Parker, P. J. (1996). 12-O-Tetradecanoylphorbol-13-acetate-induced dephosphorylation of protein kinase Calpha correlates with the presence of a membrane-associated protein phosphatase 2A heterotrimer. J. Biol. Chem. 271, 32785-32788. doi: 10.1074/ jbc.271.51.32785

Hei, Z. Q., Gan, X. L., Huang, P. J., Wei, J., Shen, N., and Gao, W. L. (2008). Influence of ketotifen, cromolyn sodium, and compound $48 / 80$ on the survival rates after intestinal ischemia reperfusion injury in rats. BMC Gastroenterol. 8:42. doi: 10.1186/1471-230X-8-42

Heinke, S., Szücs, G., Norris, A., Droogmans, G., and Nilius, B. (1995). Inhibition of volume-activated chloride currents in endothelial cells by chromones. Br. J. Pharmacol. 115, 1393-1398. doi: 10.1111/j.1476-5381.1995. tb16629.x

Hirata, F. (1981). The regulation of lipomodulin, a phospholipase inhibitory protein, in rabbit neutrophils by phosphorylation. J. Biol. Chem. 256, 7730-7733.

Hoshino, M., and Nakamura, Y. (1997). The effect of inhaled sodium cromoglycate on cellular infiltration into the bronchial mucosa and the expression of adhesion molecules in asthmatics. Eur. Respir. J. 10, 858-865.

Howell, J. (2005). Roger Altounyan and the discovery of cromolyn (sodium cromoglycate). J. Allergy Clin. Immunol. 115, 882-885. doi: 10.1016/j.jaci.2004. 12.011
Hughes, E. L., Becker, F., Flower, R. J., Buckingham, J. C., and Gavins, F. N. E. (2017). Mast cells mediate early neutrophil recruitment and exhibit antiinflammatory properties via the formyl peptide receptor 2/lipoxin A4 receptor. Br. J. Pharmacol. 174, 2393-2408. doi: 10.1111/bph.13847

Ishizuka, T., Yamamoto, M., Nagashima, T., Kajita, K., Taniguchi, O., Yasuda, K., et al. (1995). Effect of dexamethasone and prednisolone on insulin-induced activation of protein kinase $\mathrm{C}$ in rat adipocytes and soleus muscles. Metabolism 44, 298-306. doi: 10.1016/0026-0495(95)90158-2

Jenkins, L., Brea, J., Smith, N. J., Hudson, B. D., Reilly, G., Bryant, N. J., et al. (2010). Identification of novel species-selective agonists of the G-proteincoupled receptor GPR35 that promote recruitment of $\beta$-arrestin- 2 and activate Ga13. Biochem. J. 432, 451-459. doi: 10.1042/BJ20101287

Jeong, H. J., Lee, S. A., Moon, P. D., Na, H. J., Park, R. K., Um, J. Y., et al. (2006). Alginic acid has anti-anaphylactic effects and inhibits inflammatory cytokine expression via suppression of nuclear factor-kappaB activation. Clin. Exp. Allergy 36, 785-794. doi: 10.1111/j.1365-2222.2006.02508.x

Joseph, M., and Rainey, D. K. (1992). [Basic research on nedocromil sodium]. Rev. Mal. Respir. 9(Suppl. 1), R93-R97.

Kay, A. B., Walsh, G. M., Moqbel, R., MacDonald, A. J., Nagakura, T., Carroll, M. P., et al. (1987). Disodium cromoglycate inhibits activation of human inflammatory cells in vitro. J. Allergy Clin. Immunol. 80, 1-8. doi: 10.1016/ S0091-6749(87)80183-5

Kimata, H., Fujimoto, M., and Mikawa, H. (1994). Nedocromil sodium acts directly on human B cells to inhibit immunoglobulin production without affecting cell growth. Immunology 81, 47-52.

Kneilling, M., Hültner, L., Pichler, B. J., Mailhammer, R., Morawietz, L., Solomon, S., et al. (2007). Targeted mast cell silencing protects against joint destruction and angiogenesis in experimental arthritis in mice. Arthritis Rheum. 56, 1806-1816. doi: 10.1002/art.22602

Kobayashi, Y., Ito, K., Kanda, A., Tomoda, K., Mercado, N., and Barnes, P. J. (2017). Impaired dual-specificity protein phosphatase DUSP4 reduces corticosteroid sensitivity. Mol. Pharmacol. 91, 475-481. doi: 10.1124/mol.116.107656

Lee, I. H., Lim, H. J., Yoon, S., Seong, J. K., Bae, D. S., Rhee, S. G., et al. (2008). Ahnak protein activates protein kinase C (PKC) through dissociation of the PKC-protein phosphatase 2A complex. J. Biol. Chem. 283, 6312-6320. doi: $10.1074 /$ jbc.M706878200

Lee, W. J., Kim, D. U., Lee, M. Y., and Choi, K. Y. (2007). Identification of proteins interacting with the catalytic subunit of PP2A by proteomics. Proteomics 7, 206-214. doi: 10.1002/pmic.200600480

Leung, K. B., Flint, K. C., Brostoff, J., Hudspith, B. N., Johnson, N. M., Lau, H. Y., et al. (1988). Effects of sodium cromoglycate and nedocromil sodium on histamine secretion from human lung mast cells. Thorax 43, 756-761. doi: $10.1136 /$ thx.43.10.756

Liu, J., Divoux, A., Sun, J., Zhang, J., Clément, K., Glickman, J. N., et al. (2009). Genetic deficiency and pharmacological stabilization of mast cells reduce dietinduced obesity and diabetes in mice. Nat. Med. 15, 940-945. doi: 10.1038/nm. 1994

Lucas, A. M., and Shuster, S. (1987). Cromolyn inhibition of protein kinase C activity. Biochem. Pharmacol. 36, 562-565. doi: 10.1016/0006-2952(87)90368-6

Mattoli, S., Mezzetti, M., Fasoli, A., Patalano, F., and Allegra, L. (1990). Nedocromil sodium prevents the release of 15-hydroxyeicosatetraenoic acid from human bronchial epithelial cells exposed to toluene diisocyanate in vitro. Int. Arch. Allergy Appl. Immunol. 92, 16-22. doi: 10.1159/000235218

Moss, S. E., and Morgan, R. O. (2004). The annexins. Genome Biol. 5, 219. doi: 10.1186/gb-2004-5-4-219

Nava, F., and Caputi, A. P. (1999). Central effects of cromoglycate sodium salt in rats treated with lipopolysaccharide. Eur. J. Pharmacol 367, 351-359. doi: 10.1016/S0014-2999(98)00986-8

Ng, F. S., Wong, K. Y., Guan, S. P., Mustafa, F. B., Kajiji, T. S., Bist, P., et al. (2011). Annexin-1-deficient mice exhibit spontaneous airway hyperresponsiveness and exacerbated allergen-specific antibody responses in a mouse model of asthma. Clin. Exp. Allergy 41, 1793-1803. doi: 10.1111/j.1365-2222.2011.03855.x

Norris, A. A., and Alton, E. W. (1996). Chloride transport and the action of sodium cromoglycate and nedocromil sodium in asthma. Clin. Exp. Allergy 26, 250-253. doi: 10.1111/j.1365-2222.1996.tb00088.x

Oka, T., Kalesnikoff, J., Starkl, P., Tsai, M., and Galli, S. J. (2012). Evidence questioning cromolyn's effectiveness and selectivity as a 'mast cell stabilizer' in mice. Lab. Invest. 92, 1472-1482. doi: 10.1038/labinvest.2012.116 
Okada, T., Sagara, H., Nakano, Y., Hiyama, T., and Fukuda, T. (1999). [A mechanism for the anti-inflammatory effect of nedocromil; inhibition of both adhesion molecule expression on eosinophils and endothelial cells, and eosinophil chemotactic activities]. Arerugi 48, 1322-1330.

Oliani, S. M., Christian, H. C., Manston, J., Flower, R. J., and Perretti, M. (2000). An immunocytochemical and in situ hybridization analysis of annexin 1 expression in rat mast cells: modulation by inflammation and dexamethasone. Lab. Invest. 80, 1429-1438. doi: 10.1038/labinvest. 3780150

Orr, T. S. (1989). Development of preclinical models for testing antiasthma drugs. Drugs 37(Suppl. 1), 113-116; discussion 127-136. doi: 10.2165/00003495198900371-00020

Ortega-Gutiérrez, S., Leung, D., Ficarro, S., Peters, E. C., and Cravatt, B. F. (2008). Targeted disruption of the PME-1 gene causes loss of demethylated PP2A and perinatal lethality in mice. PLOS ONE 3:e2486. doi: 10.1371/journal.pone. 0002486

Oyama, Y., Shishibori, T., Yamashita, K., Naya, T., Nakagiri, S., Maeta, H., et al. (1997). Two distinct anti-allergic drugs, amlexanox and cromolyn, bind to the same kinds of calcium binding proteins, except calmodulin, in bovine lung extract. Biochem. Biophys. Res. Commun. 240, 341-347. doi: 10.1006/bbrc.1997. 7476

Parente, L., and Solito, E. (2004). Annexin 1: more than an anti-phospholipase protein. Inflamm. Res. 53, 125-132. doi: 10.1007/s00011-003-1235-z

Park, S., Taub, M., and Han, H. (2001). Regulation of phosphate uptake in primary cultured rabbit renal proximal tubule cells by glucocorticoids: evidence for nongenomic as well as genomic mechanisms. Endocrinology 142, 710-720. doi: 10.1210/endo.142.2.7934

Pearce, F. L., Befus, A. D., Gauldie, J., and Bienenstock, J. (1982). Mucosal mast cells. II. Effects of anti-allergic compounds on histamine secretion by isolated intestinal mast cells. J. Immunol. 128, 2481-2486.

Pederzoli-Ribeil, M., Maione, F., Cooper, D., Al-Kashi, A., Dalli, J., Perretti, M., et al. (2010). Design and characterization of a cleavage-resistant Annexin A1 mutant to control inflammation in the microvasculature. Blood 116, 4288-4296. doi: 10.1182/blood-2010-02-270520

Pepinsky, R. B., Sinclair, L. K., Browning, J. L., Mattaliano, R. J., Smart, J. E., Chow, E. P., et al. (1986). Purification and partial sequence analysis of a 37-kDa protein that inhibits phospholipase A2 activity from rat peritoneal exudates. J. Biol. Chem. 261, 4239-4246.

Perretti, M., Ahluwalia, A., Harris, J. G., Goulding, N. J., and Flower, R. J. (1993). Lipocortin-1 fragments inhibit neutrophil accumulation and neutrophildependent edema in the mouse. A qualitative comparison with an anti-CD11b monoclonal antibody. J. Immunol. 151, 4306-4314.

Perretti, M., Ahluwalia, A., Harris, J. G., Harris, H. J., Wheller, S. K., and Flower, R. J. (1996). Acute inflammatory response in the mouse: exacerbation by immunoneutralization of lipocortin 1. Br. J. Pharmacol. 117, 1145-1154. doi: 10.1111/j.1476-5381.1996.tb16709.x

Perretti, M., and D'Acquisto, F. (2009). Annexin A1 and glucocorticoids as effectors of the resolution of inflammation. Nat. Rev. Immunol. 9, 62-70. doi: 10.1038/ nri2 240

Plotkin, L. I., Manolagas, S. C., and Bellido, T. (2007). Glucocorticoids induce osteocyte apoptosis by blocking focal adhesion kinase-mediated survival. Evidence for inside-out signaling leading to anoikis. J. Biol. Chem. 282, 24120-24130. doi: 10.1074/jbc.M611435200

Qiu, J., Wang, C. G., Huang, X. Y., and Chen, Y. Z. (2003). Nongenomic mechanism of glucocorticoid inhibition of bradykinin-induced calcium influx in PC12 cells: possible involvement of protein kinase C. Life Sci. 72, 2533-2542. doi: 10.1016/S0024-3205(03)00168-1

Radeau, T., Godard, P., Chavis, C., Michel, F. B., Descomps, B., and Damon, M. (1993). Effect of nedocromil sodium on sulfidopeptide leukotrienes-stimulated human alveolar macrophages in asthma. Pulm. Pharmacol. 6, 27-31. doi: 10.1006/pulp.1993.1005

Ramos, L., Peña, G., Cai, B., Deitch, E. A., and Ulloa, L. (2010). Mast cell stabilization improves survival by preventing apoptosis in sepsis. J. Immunol. 185, 709-716. doi: 10.4049/jimmunol.1000273

Raynal, P., and Pollard, H. B. (1994). Annexins: the problem of assessing the biological role for a gene family of multifunctional calcium- and phospholipidbinding proteins. Biochim. Biophys. Acta 1197, 63-93. doi: 10.1016/03044157(94)90019- 1
Ricciarelli, R., and Azzi, A. (1998). Regulation of recombinant PKC alpha activity by protein phosphatase 1 and protein phosphatase 2A. Arch. Biochem. Biophys. 355, 197-200. doi: 10.1006/abbi.1998.0732

Rintala, R. J., and Lindahl, H. (2001). Sodium cromoglycate in the management of chronic or recurrent enterocolitis in patients with Hirschsprung's disease. J. Pediatr. Surg. 36, 1032-1035. doi: 10.1053/jpsu.2001.24732

Roviezzo, F., Getting, S. J., Paul-Clark, M. J., Yona, S., Gavins, F. N., Perretti, M., et al. (2002). The annexin-1 knockout mouse: what it tells us about the inflammatory response. J. Physiol. Pharmacol. 53, 541-553.

Russo-Marie, F., and Duval, D. (1982). Dexamethasone-induced inhibition of prostaglandin production dose not result from a direct action on phospholipase activities but is mediated through a steroid-inducible factor. Biochim. Biophys. Acta 712, 177-185. doi: 10.1016/0005-2760(82)90100-X

Rusznak, C., Devalia, J. L., Sapsford, R. J., and Davies, R. J. (1996). Ozoneinduced mediator release from human bronchial epithelial cells in vitro and the influence of nedocromil sodium. Eur. Respir. J. 9, 2298-2305. doi: 10.1183/ 09031936.96.09112298

Sacco, O., Lantero, S., Scarso, L., Galietta, L. J., Spallarossa, D., Silvestri, M., et al. (1999). Modulation of HLA-DR antigen and ICAM-1 molecule expression on airway epithelial cells by sodium nedocromil. Ann. Allergy Asthma Immunol. 83, 49-54. doi: 10.1016/S1081-1206(10)63512-0

Sadeghi-Hashjin, G., Nijkamp, F. P., Henricks, P. A., and Folkerts, G. (2002). Sodium cromoglycate and doxantrazole are oxygen radical scavengers. Eur. Respir. J. 20, 867-872. doi: 10.1183/09031936.02.00382002

Sagi-Eisenberg, R. (1985). Possible role for a calcium-activated, phospholipiddependent protein kinase in mode of action of DSCG. Trends Pharmacol. Sci. 6, 198-200. doi: 10.1016/0165-6147(85)90094-X

Schwender, C. F. (1981). Human leukocyte alkaline phosphatase inhibition by allergic mediator release inhibitors. Biochem. Pharmacol. 30, 217-222. doi: 10.1016/0006-2952(81)90081-2

Schwender, C. F., Sunday, B. R., and Decker, V. L. (1982). Alkaline phosphatase inhibition by a series of pyrido[2,1-b]quinazolines: a possible relationship with cromolyn-like antiallergy activity. J. Med. Chem. 25, 742-745. doi: 10.1021/ jm00348a025

Shichijo, M., Inagaki, N., Nakai, N., Kimata, M., Nakahata, T., Serizawa, I., et al. (1998). The effects of anti-asthma drugs on mediator release from cultured human mast cells. Clin. Exp. Allergy 28, 1228-1236. doi: 10.1046/j.1365-2222. 1998.00394.x

Shishibori, T., Oyama, Y., Matsushita, O., Yamashita, K., Furuichi, H., Okabe, A., et al. (1999). Three distinct anti-allergic drugs, amlexanox, cromolyn and tranilast, bind to S100A12 and S100A13 of the S100 protein family. Biochem. J. 338( Pt 3), 583-589.

Sim, A. T., and Scott, J. D. (1999). Targeting of PKA, PKC and protein phosphatases to cellular microdomains. Cell Calcium 26, 209-217. doi: 10.1054/ceca.1999. 0072

Sinniah, A., Yazid, S., Perretti, M., Solito, E., and Flower, R. J. (2016). The role of the Annexin-A1/FPR2 system in the regulation of mast cell degranulation provoked by compound $48 / 80$ and in the inhibitory action of nedocromil. Int. Immunopharmacol. 32, 87-95. doi: 10.1016/j.intimp.2016.01.003

Solito, E., Christian, H. C., Festa, M., Mulla, A., Tierney, T., Flower, R. J., et al. (2006). Post-translational modification plays an essential role in the translocation of annexin A1 from the cytoplasm to the cell surface. FASEB J. 20, 1498-1500. doi: 10.1096/fj.05-5319fje

Solito, E., Mulla, A., Morris, J. F., Christian, H. C., Flower, R. J., and Buckingham, J. C. (2003). Dexamethasone induces rapid serine-phosphorylation and membrane translocation of annexin 1 in a human folliculostellate cell line via a novel nongenomic mechanism involving the glucocorticoid receptor, protein kinase $\mathrm{C}$, phosphatidylinositol 3-kinase, and mitogen-activated protein kinase. Endocrinology 144, 1164-1174. doi: 10.1210/en.2002-220592

Sung, C. P., Saunders, H. L., Krell, R. D., and Chakrin, L. W. (1977a). Studies on the mechanism of tachyphylaxis to disodium cromoglycate. Int. Arch. Allergy Appl. Immunol. 55, 374-384.

Sung, C. P., Saunders, H. L., Lenhardt, E., and Chakrin, L. W. (1977b). Further studies on the tachyphylaxis to DSCG. The effects of concentration and temperature. Int. Arch. Allergy Appl. Immunol. 55, 385-394.

Szkudlińska, B., Kowalski, M. L., Grzegorczyk, J., and Pierzchała, A. (1996). [Chemotactic activity of neutrophils from atopic and non-atopic subjects-effect of sodium cromoglycate (DSCG)]. Pneumonol. Alergol. Pol. 64, 379-385. 
Taylor, A. D., Christian, H. C., Morris, J. F., Flower, R. J., and Buckingham, J. C. (1997). An antisense oligodeoxynucleotide to lipocortin 1 reverses the inhibitory actions of dexamethasone on the release of adrenocorticotropin from rat pituitary tissue in vitro. Endocrinology 138, 2909-2918. doi: 10.1210/endo. 138.7.5260

Teixeira, M. M., Das, A. M., Miotla, J. M., Perretti, M., and Hellewell, P. G. (1998). The role of lipocortin-1 in the inhibitory action of dexamethasone on eosinophil trafficking in cutaneous inflammatory reactions in the mouse. Br. J. Pharmacol. 123, 538-544. doi: 10.1038/sj.bjp.0701625

Theoharides, T. C., Sieghart, W., Greengard, P., and Douglas, W. W. (1980). Antiallergic drug cromolyn may inhibit histamine secretion by regulating phosphorylation of a mast cell protein. Science 207, 80-82. doi: 10.1126/science. 6153130

Theoharides, T. C., Wang, L., Pang, X., Letourneau, R., Culm, K. E., Basu, S., et al. (2000). Cloning and cellular localization of the rat mast cell $78-\mathrm{kDa}$ protein phosphorylated in response to the mast cell "stabilizer" cromolyn. J. Pharmacol. Exp. Ther. 294, 810-821.

Thomson, D. S., and Evans, D. P. (1973). Inhibition of immediate hypersensitivity reactions by disodium cromoglycate. Clin. Exp. Immunol. 13, 537-544.

Vane, J. R. (1971). Inhibition of prostaglandin synthesis as a mechanism of action for aspirin-like drugs. Nat. New Biol. 231, 232-235. doi: 10.1038/ newbio231232a0

Vural, K. M., Liao, H., Oz, M. C., and Pinsky, D. J. (2000). Effects of mast cell membrane stabilizing agents in a rat lung ischemia-reperfusion model. Ann. Thorac. Surg. 69, 228-232. doi: 10.1016/S0003-4975(99) 01052-8

Wallner, B. P., Mattaliano, R. J., Hession, C., Cate, R. L., Tizard, R., Sinclair, L. K., et al. (1986). Cloning and expression of human lipocortin, a phospholipase A2 inhibitor with potential anti-inflammatory activity. Nature 320, 77-81. doi: $10.1038 / 320077 \mathrm{a} 0$

Walther, A., Riehemann, K., and Gerke, V. (2000). A novel ligand of the formyl peptide receptor: annexin I regulates neutrophil extravasation by interacting with the FPR. Mol. Cell 5, 831-840. doi: 10.1016/S1097-2765(00)80323-8

Wang, J., Simonavicius, N., Wu, X., Swaminath, G., Reagan, J., Tian, H., et al. (2006). Kynurenic acid as a ligand for orphan $G$ protein-coupled receptor GPR35. J. Biol. Chem. 281, 22021-22028. doi: 10.1074/jbc.M603503200

Wang, L., Correia, I., Basu, S., and Theoharides, T. C. (1999). Ca2+ and phorbol ester effect on the mast cell phosphoprotein induced by cromolyn. Eur. J. Pharmacol. 371, 241-249. doi: 10.1016/S0014-2999(99)00179-X

Wells, E., and Mann, J. (1983). Phosphorylation of a mast cell protein in response to treatment with anti-allergic compounds. Implications for the mode of action of sodium cromoglycate. Biochem. Pharmacol. 32, 837-842. doi: 10.1016/00062952(83)90585-3

Wu, C. C., Croxtall, J. D., Perretti, M., Bryant, C. E., Thiemermann, C., Flower, R. J., et al. (1995). Lipocortin 1 mediates the inhibition by dexamethasone of the induction by endotoxin of nitric oxide synthase in the rat. Proc. Natl. Acad. Sci. U.S.A. 92, 3473-3477. doi: 10.1073/pnas.92.8.3473

Wyss, D., Bonneau, O., and Trifilieff, A. (2005). Mast cell involvement in the adenosine mediated airway hyper-reactivity in a murine model of ovalbumininduced lung inflammation. Br. J. Pharmacol. 145, 845-852. doi: 10.1038/sj.bjp. 0706271
Xue, M., Hsieh, G., Raymond-Stintz, M. A., Pfeiffer, J., Roberts, D., Steinberg, S. L., et al. (2007). Activated N-formyl peptide receptor and high-affinity IgE receptor occupy common domains for signaling and internalization. Mol. Biol. Cell 18, 1410-1420. doi: 10.1091/mbc.E05-11-1073

Yamawaki, I., Tamaoki, J., Takeda, Y., and Nagai, A. (1997). Inhaled cromoglycate reduces airway neurogenic inflammation via tachykinin antagonism. Res. Commun. Mol. Pathol. Pharmacol. 98, 265-272.

Yang, Y., Lu, J. Y., Wu, X., Summer, S., Whoriskey, J., Saris, C., et al. (2010). G-protein-coupled receptor 35 is a target of the asthma drugs cromolyn disodium and nedocromil sodium. Pharmacology 86, 1-5. doi: 10.1159/ 000314164

Yazid, S., Ayoub, S. S., Solito, E., McArthur, S., Vo, P., Dufton, N., et al. (2010a). Anti-allergic drugs and the Annexin-A1 system. Pharmacol. Rep. 62, 511-517.

Yazid, S., Leoni, G., Getting, S. J., Cooper, D., Solito, E., Perretti, M., et al. (2010b). Antiallergic cromones inhibit neutrophil recruitment onto vascular endothelium via annexin-A1 mobilization. Arterioscler. Thromb. Vasc. Biol. 30, 1718-1724. doi: 10.1161/ATVBAHA.110.209536

Yazid, S., Sinniah, A., Solito, E., Calder, V., and Flower, R. J. (2013). Anti-allergic cromones inhibit histamine and eicosanoid release from activated human and murine mast cells by releasing annexin A1. PLOS ONE 8:e58963. doi: 10.1371/ journal.pone.0058963

Yazid, S., Solito, E., Christian, H., McArthur, S., Goulding, N., and Flower, R. (2009). Cromoglycate drugs suppress eicosanoid generation in U937 cells by promoting the release of Anx-A1. Biochem. Pharmacol. 77, 1814-1826. doi: 10.1016/j.bcp.2009.03.010

Yoo, S. J., Boylan, J. M., Brautigan, D. L., and Gruppuso, P. A. (2007). Subunit composition and developmental regulation of hepatic protein phosphatase $2 \mathrm{~A}$ (PP2A). Arch. Biochem. Biophys. 461, 186-193. doi: 10.1016/j.abb.2007.02.019

Zhang, D., Kanthasamy, A., Yang, Y., and Anantharam, V. (2007). Protein kinase C delta negatively regulates tyrosine hydroxylase activity and dopamine synthesis by enhancing protein phosphatase-2A activity in dopaminergic neurons. J. Neurosci. 27, 5349-5362. doi: 10.1523/JNEUROSCI.4107-06.2007

Zhang, S., Dong, H., Zhang, X., Li, N., Sun, J., and Qian, Y. (2016). Cerebral mast cells contribute to postoperative cognitive dysfunction by promoting blood brain barrier disruption. Behav. Brain Res. 298, 158-166. doi: 10.1016/j.bbr. 2015.11.003

Zhang, X., Dong, H., Li, N., Zhang, S., Sun, J., and Qian, Y. (2016). Activated brain mast cells contribute to postoperative cognitive dysfunction by evoking microglia activation and neuronal apoptosis. J. Neuroinflammation 13, 127. doi: 10.1186/s12974-016-0592-9

Conflict of Interest Statement: The authors declare that the research was conducted in the absence of any commercial or financial relationships that could be construed as a potential conflict of interest.

Copyright (c) 2017 Sinniah, Yazid and Flower. This is an open-access article distributed under the terms of the Creative Commons Attribution License (CC BY). The use, distribution or reproduction in other forums is permitted, provided the original author(s) or licensor are credited and that the original publication in this journal is cited, in accordance with accepted academic practice. No use, distribution or reproduction is permitted which does not comply with these terms. 